presence of inverted micelles at the fusion site of two well separated bilayers ${ }^{11}$.

A. J. VERKLEIJ
B. DE KRUIJFF
Institute of Molecular Biology,
State University of Utrecht,
PO Box 80.063,
3508 TB Utrecht,
The Netherlands

1. Verkleij, A. J., Mombers, C., Leunissen-Bijvelt, J. \& Ververgaert, P. H. J. Th. Nature 279, 162-163 (1979) de Kruijff, B. et al. Biochim. biophys. Acta 555, 200-209 (1979)

3. Verkleij. A. J., Mombers, C., Gerritsen, W. J., LeunissenBijvelt, J. \& Cullis, P. R. Biochim. biophys. Acta 555 , 358-362 (1979)

4. Verkleij, A. J., van Echteld, C. J. A., Gerritsen, W. J., Cultis, P. R. \& de Kruijff, B. Biochim. biophys. Acta 600 $620-624(1980)$

5. de Kruijff. B., Cullis, P. R. \& Verkleij, A. J. Trends biochem. Sci. 5, 79-81 (1980).

6. Miller, R. G. Nature 287, 166-167 (1980).

7. van Venetie, R., Leunissen-Bijvelt, J. \& Verkleij, A. J. Biochim biophys. Acta (submitted).

8. Luzzati. V., Reiss-Husson, F., Rivas, E. \& Gulik-Krzy wicki, T. Ann N.Y Acad Sci. 137, 409-413 (1966). Cullis, P. R. \& de Kruijff, B. Biochim. biophys. Acta 559 399-420 (1979).

10. Cullis, P. R., de Kruijft, B., Hope, M. J., Nayar, R. \& Schmidt, S. Can. J. Biochem. 58, $1091-1100$ (1980).

11. Verkieij, A. J. et al. (in preparation).

\section{Fossil charcoal and the palaeoatmosphere}

IT has been proposed by Cope and Chaloner $^{1}$ that oxygen levels in palaeoatmospheres may be assessed by the presence or absence of charcoal in the geological record. Although oxygen is required for burning, it is not necessary for charcoal formation. When wood is subjected to high temperatures, oxygenbearing gases are evolved, yielding an oxygen-depleted graphitic network (charcoal) $^{2}$. Charcoal formation is favoured by low oxygen concentrations at the solid surface and forms in anoxic conditions at temperatures above $200^{\circ} \mathrm{C}$. In the remote past, however, heat from wood fires, sustained by atmospheric oxygen, was probably the dominant agent for charcoal formation. Thus, the coupling of atmospheric oxygen concentration to charcoal formation may not be as direct as has been proposed.

That the occurrence of charcoal is determined by the oxygen concentration required for carbon monoxide or methane to burn, as Cope and Chaloner presume, has not been demonstrated. Depending on configuration, ignited wood samples may not continue to burn in atmospheres containing as much as $13-21 \%$ oxygen $^{3}$. At lower concentrations the most likely source of heat for charcoal formation would not be available.

It is not known whether palaeoatmospheric pressures were identical to present-day values. The proportion of oxygen required for ignition depends on the pressure ${ }^{4}$, but the dependence has not been investigated for wood. If inert gas is added to air, as in submarines, the partial pressure of oxygen and consequently respiration are unaffected, but the proportion of oxygen may be reduced sufficiently to prevent a match from burning .

While applauding the cross-disciplinary approach of Cope and Chaloner, we caution that the effects we have described should be considered before this potentially valuable probe of palaeoatmospheric composition be used. With refinement, this might be extended to explore fascinating problems, such as atmospheric implications of expanding Earth models and the effects of oxygen and carbon dioxide partial pressures on photosynthesis ${ }^{6-8}$ in the past.

Fire Research Section,

$$
\text { F. R. S. ClARK }
$$

National Research Council of Canada,

Ottawa, Canada K1A OR6

\section{Paleobiology Division, \\ National Museum of Natural}

$$
\text { D. A. Russell }
$$

Sciences,

Ottawa, Canada K1A OM8

1. Cope, M. J. \& Chaloner, W. G. Nature 283, 647-649 (1980).

2. Browne, F. L. Report 2136 18-19 (Forest Products Laboratory, Madison, Wisconsin, 1958).

3. Rasbash, D. J. \& Langford, B. Combustion Flame 12, 33-40 (1968).

4. Wharton, R. K. Fire Mater. 3, 39-48 (1979).

5. Carhart, H. W. Nat. Symp. Fire Aspects of Polymeric Materials (American Chemical Society, June. 1977).

6. Gardescu, J. \& Hagar, W. G. Pl. Physiol. 65, Suppl. 6, 12 (1980)

7. Vidaver, W. \& Hall, G. Pl. Physiol. 65, Suppl. 6, 13 (1980)

8. Rogers, H. H., Sinclair, T. R. \& Heck, W. W. Pl. Physiol 65. Suppl. 6. 49 (1980).

Chaloner and COPE REPLYAlthough we are aware that charcoal may be produced in a variety of physical conditions, we must stress that the theme of our letter was to examine the palaeoatmospheric implications of our studies of the widespread distribution of charcoal (fusinite) in the geological record. We did not attempt to present a comprehensive survey of the conditions of charcoal formation.

In the natural environment, charcoal may be produced in conditions of both pyrolysis and combustion, but the mechanisms for charcoal formation are few. First, basalt laval flows are known to engulf vegetation and subject the included woody tissues to pyrolysis, transforming these into charcoal ${ }^{1}$. Second, in swamp peat accumulations, local temperature rise caused by exothermic decomposition reactions may initiate smouldering which could produce charcoal. Third, and most important, combustion of vegetation by forest fire can result in the production of large volumes of charcoal as a residue. It is the last mechanism which we believe to be responsible for the generation of the greater proportion of charcoalified phytoclasts which occur in ancient sediments. Thus, our suggested implication for past atmospheric composition is not based on the range of physical conditions for charcoal production but on the restriction (in terms of oxygen level) which can be placed on the occurrence of largescale natural burning, that is, the combustion associated with forest fire. We placed this restriction at a minimum oxygen level of $\sim 0.3$ present atmospheric level (PAL). We acknowledge that it may be possible to produce charcoal in special circumstances with oxygen levels $<0.3 \mathrm{PAL}$. However, at such levels it would not be possible to maintain the combustion mechanism for the production of the large quantity of charcoal preserved in the geological record, estimated to be $4 \times 10^{5}-4 \times 10^{7}$ tons in post-Silurian rocks ${ }^{2}$.

Since the publication of our letter we have learned (K. N. Palmer, personal communication) that the combustion levels of carbon monoxide and methane described in the experiments of Coward and $\mathrm{Jones}^{3}$ were based on pre-mixed flames. In conditions of natural burning the combustion is by diffusion flames, where the minimum level of oxygen required to support combustion is more likely to be $\sim 13 \% \quad(\sim 0.6 \mathrm{PAL})$, corresponding to the lower levels of oxygen concentration in the extinction experiments of Rasbash and Langford ${ }^{4}$. Thus, we are able to revise our minimum estimate to $\sim 0.6 \mathrm{PAL}$, thereby placing further constraints on estimates of oxygen concentration in post-Silurian atmospheres.

The question of increased atmospheric pressures is interesting. Since it is generally accepted that the oxygen in the Earth's atmosphere has accumulated steadily from photosynthetic build-up, any proposed models of palaeoatmospheres should set the partial pressure of oxygen at or about its present level. Presumably, for an oxygen/nitrogen palaeoatmosphere at higher than presentday atmospheric pressure, the implied increased partial pressure of nitrogen would have to be accounted for by increased rates of volcanic outgassing in the past. We do not know of any geological evidence to support or reject this type of model, and therefore can make no further comment on this aspect. In the absence of such data we can only assume that past atmospheric pressures were similar to those of the present day. In such conditions we offer the occurrence of charcoal in the sedimentary record as a valuable geological indicator in any proposed palaeoatmospheric models.

Department of Botany,

M. J. COPE W. G. Chaloner

Bedford College,

Regent's Park,

London NW1 4NS, UK

Lockwood, J. P. \& Williams, J. S. (ieol. Mag. 115, 69-74 (1978)

2. Cope, M. J in Organic Maturation of Sedimentary Organic Matters. Preservation Problems and Fossil Fuel Explora tion (ed. Brooks, J.) (Academic, New York, in the press).

3. Coward, H F \& Jones, G. W Bu I U S. Bur. Mines. 503 (1952).

4. Rasbash, D. J. \& Langford, B. Combustion Flame 12, 33-40 (1968). 